\title{
MUSICAL MODERNISM IN THE TWENTIETH CENTURY
}

\section{R. Franki S. Notosudirdjo}

This chapter addresses the issue of musical exchange between Indonesians and Dutch. This exchange contributed significantly to the birth of a new idiom and aesthetics prevalent in what was to be the global history of twentieth century music. Composers involved in this exchange were, on the Indonesian side, R.M. Soewardi Soerjaningrat, R.M. Soerjo Poetro, R. Atmadarsana, R. Soehardjo and R. Machjar Angga Koesoemadinata; and, on the Dutch side, included the likes of Mrs Hoffman (Linda Bandara), Dirk Schäfer, Emiel Hullebroeck, Bernard van den Sigtenhorst, Henk Bading, Fred Belloni, Constant van de Wall and Paul Seelig, some of whom are also referred to elsewhere in this volume.

By the end of ninteenth century, an urban mestizo lifestyle, which had developed the European music culture in the Archipelago for several hundred years, had deeply penetrated the life of local elites. In the case of Java, the role of the local nobility was crucial, as they were among the groups of people who had access to the education provided by the colonial government. As a result, the nobility received a considerable introduction to European music through public schools, especially the Dutch Kweekschool (vocational school). In the early twentieth century, the Kweekschool emerged as a social institution capable of producing modern indigenous composers and intellectuals. It was in this context that Indonesian composers began to engage in the pursuit of cultural expression by means of an individual musical language and aesthetics that was associated with the style of 'modern music'. Hence, it indicated the birth of Indonesian art music or musik seni.

\section{Ki Hadjar Dewantara and the Birth of Indonesian Art Music}

The pioneer composer, responsible for the genesis of twentieth century Indonesian art music, is R.M. Soewardi Soerjaningrat, better known as Ki Hadjar Dewantara. He was a member of the Paku Alaman court and an alumnus of the Yogyakarta Kweekschool. In 1916, Ki Hadjar composed a piece of music for soprano and piano called Kinanthie Sandoong. Although 
Kinanthie Sandoong was derived from a Javanese Macapat verse form with the same name, Ki Hadjar's score bears his own (free) interpretation and new musical ideas similar to the practice of art music in the Western world.

First, the piece was written for soprano and piano, a musical form and instrumentation unknown to the gamelan tradition. Second, the piano transcription was based on the gender part, a metallophone gamelan instrument that functions in a quasi-improvisatory way in gendhing and relies on a somewhat personal expression. Third, Ki Hadjar employed a concept of harmony (triad chord and a bass line) that is also unknown to gamelan tradition. Hence, Ki Hadjar transformed Kinanthie Sandoong from a traditional gendhing into a Western model of art music composition. What makes this piece intriguing is that, in performing it, the composer demands the vocalist sing by employing cengkok-wilet, a traditional pattern of improvisation and melodic embellishment in gamelan. As a result, although Kinanthie Sandoong was inspired by European art music, its melodic structure, compositional texture and performance style of the vocal parts still very much work in the manner of Javanese traditional music. Hence, it harmoniously blends Western and indigenous (music) cultures, an ideal which was soon to be pursued by both indigenous and Dutch intellectuals.

In addition to its unique compositional idea, Kinanthie Sandoong also posed a serious challenge to musicians. By employing two musical systems together it could only be performed by a singer who had mastered both Western classical as well as traditional Javanese music. At the time when Kinanthie Sandoong was written, it is hard to imagine how Western musicians or indigenous musicians could resolve such a challenge.

Ki Hadjar was, in fact, the first composer to introduce this problematic new aesthetic endeavour. Drawing his inspiration from Sastra Gendhing, he stated that music should be able to express the innermost soul of a human being (see Ki Hadjar Dewantara 1967: 194-200). For this reason, Ki Hadjar insisted that music should come from a human being who has freedom in performance. A piece of music that employs full notation, according to Ki Hadjar, will not be able to express the innermost soul of a human being, because the player does not have freedom while playing. Notation, in his opinion, should be employed only as a general scheme of composition. It was for this reason that Ki Hadjar demanded that the vocal part of Kinanthie Sandoong should be executed by employing the unnotated cengkok-wilet of gamelan that bears a personal freedom.

In so doing, Ki Hadjar could avoid what he thought of as the weakness of European classical music. He suggested that (new) Indonesian music 
should not employ full notation, but rather leave room for musicians to directly and spontaneously express their own innermost feeling while they are playing (Ki Hadjar Dewantara 1967: 194-200). This is basically the teaching of Sastra Gendhing: a man who does not understand gendhing (music) is an imperfect man (Ki Hadjar Dewantara 1967: 194-200). Music, according to Sastra Gendhing, is the only art form that is capable of expressing the innermost soul of human beings. Therefore, music, in addition to knowledge (sastra), has a very important role for mankind.

An article entitled 'Toonkunst in de toekomst' (The future of music), which appeared in the journal Wederopbouw, discussed Kinanthie Sandoong as one of the models for music of the future, albeit in a critical manner (Toonkunst 1920: 75-76). The problems that this anonymous critic had with Kinanthie Sandoong - having heard the performance - was that this piece sounded 'too Western', for it employed the Western diatonic scale and instrumentation (piano and voice). Consequently, from the strict Javanese point of view advocated by the critic, this piece lost its 'Javanese essence'. Hence, to the critic, the music '[...] did not satisfy us. Gave us no originality, did not impress us, and did not move us' (Toonkunst 1920: 75-76). The critic even accused this piece of being political, for it was conceived with the spirit of Indonesian nationalism. The author goes on to say:

The mistake made by this Indonesian-nationalist is that he tried to Europeanize the Javanese Eastern cultural product. Culture demands other creational values than government and politics. ${ }^{1}$

Indeed, in addition to aesthetic motivations, Ki Hadjar composed his Kinanthie Sandoong with a certain political agenda in mind. Let me discuss further Ki Hadjar's background and the political situation behind the birth of the piece.

\section{Nationalist Aspirations}

Many members of the Paku Alaman family, who received high levels of Western education at local Dutch schools or abroad, became deeply involved in the nationalist movement of the early twentieth century.

1 Translated from the Dutch: 'Een fout van dezen Indisch-nationalist, dat hij de Javaansche Oostersche cultuuruiting verindischen wilt op Europeesche leest. Cultuur eischt teneenemale andere scheppingswaarden dan staatkunde en politiek' (Toonkunst 1920: 76). 
Ki Hadjar Dewantara is no exception to this. By the time he enrolled in STOVIA, a medical school in Batavia, Ki Hadjar was already active in writing and presenting his nationalist views in various newspapers. STOVIA was a school for the cream of Indonesian society. It was at this school that Ki Hadjar met nationalist colleagues, such as R. Soetomo and Tjipto Mangoenkoesoemo, and developed his nationalist ideology.

Ernest Douwes Dekker (grandson of Multatuli), one of the most influential leaders of the Indies nationalist movement, also had regular contact with STOVIA students. Douwes Dekker was the first to introduce the idea of forming the East Indies as an independent country (Surjomihardjo 1979: 448). When Soetomo founded Boedi Oetoemo in 1908, Ki Hadjar joined this first Javanese nationalist cultural organization. However, as Boedi Oetomo's view on nationalism developed towards conservative Java-centricism, Ki Hadjar left the organization (Hatta 1977: 8). He was, thus, one of the first Javanese intellectuals to conceive the East Indies as an independent nation-state and to devote himself to realizing such an objective. In 1912, when he joined Sarekat Islam - the largest Islam-based social organization in the East Indies - and became the leader of the Bandung (West Java) branch, Ki Hadjar even 'challenged the central leadership and proposed dropping the Moslem qualification from the membership requirements' (Shiraishi 1990: 59).

Finally, in 1912 Ki Hadjar Dewantara, Douwes Dekker and Tjipto Mangoenkoesoemo founded their own organization, the Indische Partij. This organization turned out to be the first political party in the East Indies, bearing a radical East Indian nationalist ideology. The Indische Partij was the first political institution with a vision of the East Indies as a fully independent nation-state. Their political aims included: (1) to establish a nation consisting of all ethnic groups in the Indies; (2) to eliminate racial discrimination within the Indies; (3) to fight against sectarian attitudes and to develop collaboration among ethnic groups; (4) to establish the Indies national defence; and (5) to develop the East Indies economy (see Surjomihardjo 1979: 448-489).

As a journalist-activist, Ki Hadjar's role was central in pursuing this entire political agenda. In his writings in the 1910s, he was also the first person to use the word 'Indonesia' in a political sense, rather than an ethnographic one. Based on this evidence, I disagree with Jennifer Lindsay who argues that Ki Hadjar Dewantara's view on nationalism is Javacentric (see Lindsay 1991). In fact, Ki Hadjar was among the first Indonesian intellectuals to perceive the people of the East Indies as one nation, and he struggled to gain Indonesian independence through various paths, 
such as journalism, politics, education, but also prominently through arts and culture.

In 1913, Ki Hadjar published an article entitled 'Als ik een Nederlander was' (If I were a Dutchman) that resulted in his exile to Holland by the colonial government. This article was written in response to the colonial government's appeal to people in the colony to celebrate one hundred years of Dutch independence. As the Indonesian people were themselves colonized, Ki Hadjar reacted strongly against this idea. Ki Hadjar cynically said:

According to my opinion, it is rather impolite, shameful, and uncivilized that we - as I imagined myself a Netherlander - ask indigenous people to happily celebrate our independence as a nation and country. First and certainly, we will hurt their feeling because we, in their country that we have colonized, celebrate our own independence day. We are happy because one hundred years ago we were liberated from foreign colonizers; and how will this be seen by those whom we have colonized, who certainly also hope that someday they will celebrate their independence day? Or do we think that these indigenous peoples do not have feelings any longer as a result of our politics of colonization having oppressed and destroyed their feeling? If that were what we really thought, our politics had certainly failed, for each people, even those who are uncivilized, in fact, refused any form of oppression. If I were a Netherlander, I would never celebrate Independence Day in a land where we do not give its people independence. Based on this thought, it is not only unfair, but it is also inappropriate to ask funding from the people of this land to fund parties. We have already humiliated them by celebrating our independence day and yet we also want to exploit their money. What an act of spiritual and material humiliation! ${ }^{2}$

2 Translated from the Dutch: 'Daar ligt dunkt me, zoo iets van onwelvoegelijkheid in, het lijkt me zo ongegeneerd, zo ongepast, indien wij - ik ben nog altijd Nederlander in verbeelding - den inlander laten mede juichen bij de herdenking onzer onafhankelijkheid. Wij kwetsen hen eerstens in hun fijn eergevoel, doordat wij hier in hun geboorteland, waar wij overheerschen, onze eigen vrijheid herdenken. Wij jubelen thans, omdat we honderd jaren geleden verlost werden van een vreemde heerschappij; en dit alles zal nu plaats hebben ten aanschouwe van hen, die nu nog steeds onder onze heerschappij staan. Zouden wij niet denken, dat die arme geknechten ook niet snakten naar het ogenblik, dat ze evenals wij nu, eenmaal zulke feesten zouden kunnen vieren?! Of meenden wij soms, dat wij door onze lang doorgezette, geestdodende fnuik-politiek den inboorlingen alle menselijke zielsgevoelens hadden gedood? Dan zouden wij toch zeer zeker bedrogen uitkomen, want zelfs de onbeschaafdste volken verwensen allen vorm van overheersching. Als ik Nederlander was, zou ik dan ook geen onafhankelijkheidsfeest vieren in een land, waar wij het volk zijn onafhankelijkheid onthouden. Geheel in de lijn van dezen gedachtengang is het onbillijk niet alleen, maar ook ongepast, om de inlanders te doen bijdragen ten bate van het feestfonds. Beledigt men ze reeds door de idée der feestelijke herdenking zelf van Nederlands vrijheid, thans maakt men ook hun beuren ledig. Voorwaar een morele en stoffelijke belediging!' (Ki Hadjar Dewantara 1952: 251-252). 
In this article, Ki Hadjar also strongly demanded that the Dutch liberate his people from colonization. As a result of the insults that he and his close relatives had often received since childhood from Dutch children, both in school and in public, Ki Hadjar had developed a spirit of resistance against the colonizers (see Bambang Sokawati Dewantara 1979, 1989a and 1989b). This had now become an open political attack on the Dutch occupation of his land. As a consequence, Ki Hadjar was considered a very dangerous person who directly threatened Dutch colonial policy in the East Indies. For this reason, Ki Hadjar - at just 24 years old - was sent to prison and, later, exiled in Holland.

Since his struggle in the political sphere had encountered coercive Dutch power, Ki Hadjar switched to culture. As an intellectual, he was quite aware that one way to fight against the colonizers was to demonstrate that indigenous people and culture were equal to the Dutch. As a musician, Ki Hadjar believed that art music signified the highest form of European musical expression. Therefore, in order to demonstrate that indigenous culture, in this case Javanese culture, could be viewed as highly as European culture, Ki Hadjar 'transformed' Kinanthie Sandoong from a traditional gendhing into a piece of modern art music.

Kinanthie Sandoong was created with this idea as a background. The piece was composed for the First Congress for Colonial Education (Eerste Koloniaal Onderwijscongres), and performed by students of the Koninklijk Conservatorium Den Haag (The Hague Royal Conservatory) on this occasion in The Hague, 28th-3oth August 1916 (Poeze 1986: 107-112). The score was then published in the prestigious Dutch East Indies periodical Nederlandsch Indie Oud en Nieuw (NION 1916: 378-379). NION had become a vehicle for Indonesian intellectuals to express their ideas and studies. This event was a crucial moment for Ki Hadjar to expose his politically grounded musical ideas. By showing the Dutch and other Europeans, both in Europe and in the colonies, that Javanese music could be rearticulated and performed in the manner of modern European art music, Ki Hadjar was principally saying 'even those who are uncivilized, in fact, refuse any form of oppression', let alone the Javanese who were as civilized as Europeans.

By employing Western notation, Ki Hadjar was also able to speak to the international community. Hence, Western notation functioned not simply as a musical notation, but as a political narrative as well. By using the colonizer's cultural code, i.e. Western notation, Ki Hadjar effectively introduced the problematic 'modern' Javanese music culture to European society. He used musical expression as resistance against the European cultural hegemony present in the Dutch colonization of the Indies. In so 
doing, Ki Hadjar turned music into - using Wallerstein's term - an ideological battleground, treating music as a political narrative against colonial power. By the same token, he was also able to speak to Europeans as a subject who controlled his own narrative, not simply as an object of European orientalism. It was only within this mind-set that Europeans could pay attention to and became aware of the problems of Dutch colonialism.

\section{R.M. Soerjo Poetro and the New (National) Music}

In pursuing the idea of music as a cultural resistance against colonialism, Ki Hadjar was not alone. His colleague composer, R.M. Soerjo Poetro was also seriously engaged in the idea of creating new music within the framework of a 'nationalist' ideology. Soerjo Poetro, in fact, was the son of Paku Alam V and Dewantara's uncle. He was sent by his parents to the Netherlands in 1909 to study civil engineering in Delft. In the middle of his study, Soerjo Poetro developed a strong interest in music and became the first Javanese music theorist-composer.

Upon his return to Yogyakarta from the Netherlands in 1921, Soerjo Poetro helped Ki Hadjar Dewantara found Taman Siswa, a school for indigenous people, based on a nationalist ideology and local cultural system. Here he was in charge as a music teacher (for both gamelan and Western music) and director of Taman Siswa's MULO-Kweekschool (junior high school-teachers' college), until he passed away in December 1927 at the age of 35 (see Ki Hadjar Dewantara 1933: 26-29 and Oedaja 1930: 141). Among his pupils was the late Tjokrowasito (known as Ki Wasistodiningrat), a renowned master of Javanese traditional gamelan music and innovative composer.

Viewed from a musical perspective, Soerjo Poetro pursued the idea of a new 'national' music even further than did Ki Hadjar. In addition to creating compositions that blended Javanese and European classical music, Soerjo Poetro also strove to develop a theory that justified his experimentation. Moreover, he also tried to construct a modern rebab (bowed lute) that could incorporate his musical ideas (Ki Hadjar Dewantara 1952: 90). Soerjo Poetro believed that the most important task for the development of new Javanese music was to conduct research on the aspects of melodic formation, theory of pathet (mode), and construction of instruments. He felt the urge to find a system of notation suitable for the new music. In pursuing all these ideals, he was quite aware of the need to encourage 
people's participation. It was in this context that he strongly emphasized the need for the development of music education for Indonesian society (Soerjo Poetro 1918: 91).

Soerjo Poetro was clearly the most articulate and productive Javanese music theorist of his generation (see Image 6.1). In my opinion, he can even be considered as the first Indonesian musicologist in the strict sense of the word. In his efforts to develop a theory of Javanese gamelan, Soerjo Poetro conducted extensive studies of Western classical music and Asian music cultures. Most of his scholarly articles were published in Dutch periodicals such as Wederopbouw, Mudato, Nederlandsch Indië Oud \& Nieuw, Weekblad voor Indië, and Hindia Poetra. Indeed, Soerjo Poetro was one of the pioneers in the field of ethnomusicology who engaged in comparative musicology as early as in the 1910s, before the Berlin School of Comparative Musicology was established by Hornbostel and his followers (see Christensen 1991: 201-209).

By the time Ki Hadjar composed Kinanthie Sandoong, Soerjo Poetro had composed a piece of vocal music called Rarjwo Sarojo and had it published in Nederlandsch Indië Oud en Nieuw (NION) in 1916. This piece was composed with ideas similar to Kinanthie Sandoong. Rarjwo Sarojo was originally a gendhing dolanan (children's song) (Sumarsam 1995: 132). Soerjo Poetro transliterated this piece into a new art music composition for violin and voice, employing his own interpretation and new musical ideas. The texture was designed in heterophonic manner, similar to gamelan. The melodies written for the voice and violin are basically the same; only the one played by the violin has embellishments added, similar to the style of rebab (string fiddle) played in gamelan. In supporting his compositional ideas, Soerjo Poetro wrote an essay on how to perform his piece on the violin or violoncello (see NION 1917-18: 317-323).

Rarjwo Sarojo was written with a new notation developed by the composer himself. In his effort to transform the oral tradition of gamelan into Western written musical system, Soerjo Poetro created a four-line staff notation in which he accommodated the Javanese fixed pitch of a pentatonic equidistant slendro and heptatonic pelog scales. This 'new' interval device certainly created fingering problems for the violinist, who usually employs the fixed pitch of the Western tuning system. In his essay, Soerjo Poetro gave instructions on how to adjust a violinist's fingering in order to perform a slendro scale with the violin. In addition, he also explained how to read his four-staff notation in relation to slendro and pelog scales. This composition not only challenges the violinist to readjust his or her conventional practice, but also challenges the conventional musical system, 


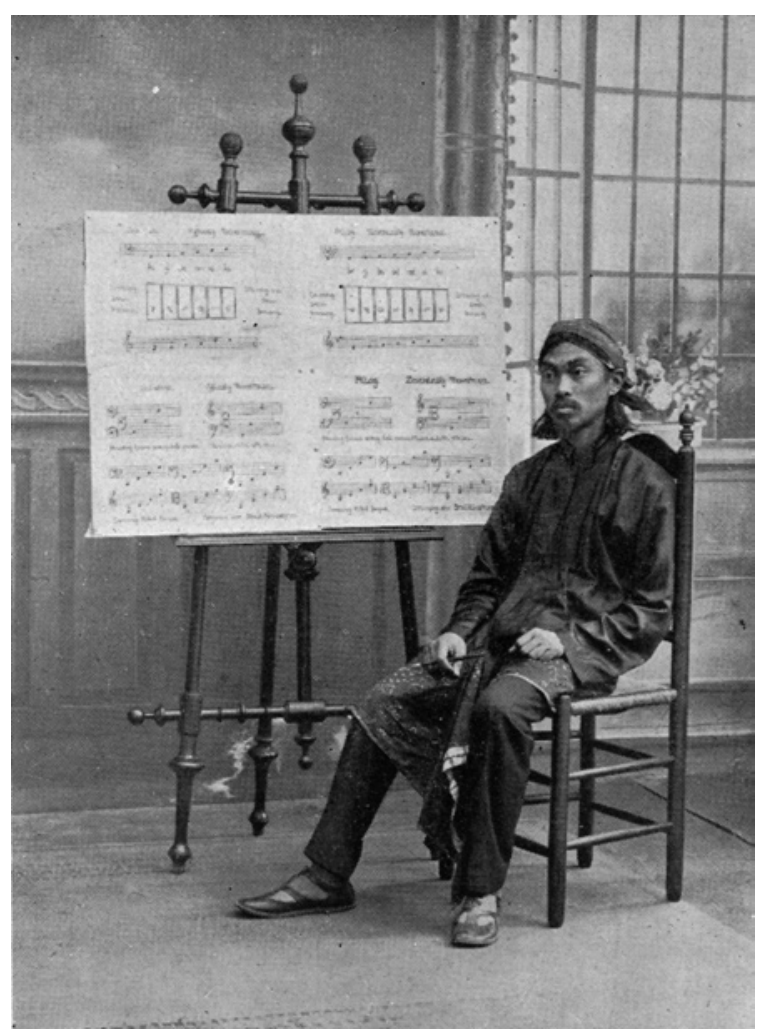

Image 6.1 R.M. Soerjo Poetro in the Netherlands in 1916 (source: Nederlandsch Indië Oud en Nieuw 5 jaargang, no. 9, 1920, page 259).

which was based on Western classical music. In this way, I would argue that both Ki Hadjar Dewantara and R.M. Soerjo Poetro were among the pioneers of new musical ideas in the world history of twentieth century music.

By the 1920s, there were other composers emerging and working on similar ideas to those employed in Kinanthie Sandoong and Rarjwo Sarojo. Among them were Atmadarsana, R. Soehardjo and R. Machjar Angga Koesoemadinata. These composers were affiliated with and actively performed in Kweekschool circles. Koesoemadinata was a teacher at Bandung Kweekschool (HIK, see also the chapter in this volume by Wim van Zanten), Atmadarsana was a graduate of Poerworedjo Hoogere Kweekschool; and R. Soehardjo was a student of the Muntilan Kweekschool. A Catholic priest known as Pater van Lith S.J. founded the Muntilan School in 1904. With its strong music programme, the Muntilan Kweekschool 
became the most prominent music institution in the colonial era. It produced prominent indigenous composers, critics and players for several generations (Budi Susanto 1990).

Atmadarsana's piece Wirangrong (1922) for two and three-part choir was composed using a traditional gendhing with the same name for his melodic material. According to Hadiwidjana, this piece was written for a slendro scale (Hadiwidjana 1925: 342-343). The treatment for Wirangrong employed a simple counterpoint technique. Two years later, R. Soehardjo, known as Hardjosubroto, composed a piece of music called Birvadda Warawidya (1924), which employed similar ideas and treatment as Wirangrong. Here, Soehardjo employed three traditional gendhings, i.e. Tarupala, Pangkur and Celunthang for melodic material (Hadiwidjana 1925: 342-343). This piece was composed for three-part choir; yet, it employed more sophisticated counterpoint techniques than Wirangrong. Although both pieces were composed using Western notation, both composers, as was the case with Kinanthie Sandoong and Rarjwo Sarojo, also demanded that the singers sing the piece in its original slendro scale and employing cengkok-wilet. Atmadarsana and Soehardjo did not simply 'transcribe' the entire gendhing into new Western notation in these compositions, as was the case with Kinanthie Sandoong and Rarjwo Sarojo. Instead, they treated these gendhing as new melodic materials and developed it into entirely new compositions. Hence, the traditional gendhing employed in Wirangrong and Birvadda Warawidya is situated in a new aesthetic realm that bears the composers' stamp more strongly. Therefore, I would argue that compared to Kinanthie Sandoong and Rarjwo Sarojo, both Wirangrong and Birvadda Warawidya embodied more advanced ideas in 'transforming' gamelan concept into art music compositions.

In the case of Machjar, his piece Ladrang Mardi Goeroe or Ladrang Pagoeron (1939?) was composed employing seemingly more complex polyphonic texture and counterpoint techniques than the four compositions mentioned earlier. This piece was written for four-part choir (SATB) in a Sundanese pelog scale. ${ }^{3}$ However, in his effort to transform pelog into a Western tuning system, Machjar recreated a new set of pelog scales based on a concept of equidistant intervals, similar to a Western chromatic scale. Here, Machjar divides one octave into nine equidistant

3 The copy of microfilm from which this material was taken is already in bad shape. However, the textural design of this piece can still give some ideas about the counterpoint techniques employed here. 
intervals of 133 cents (Machjar Koesoemadinata 1941: 60-73). In so doing, Machjar created even more difficulties for the singers, since they have to sing in a whole new pelog scale. By the same token, Machjar can also be considered as the pioneer of 'just intonation', which was developed later by a new generation of American composers such as La Monte Young.

Based on these facts, I surmise that this is a period when a new musical tradition, which I call musik seni or art music, was born in Indonesia. In this context, I would argue that Ki Hadjar Dewantara, R.M. Soerjo Poetro, Atmadarsana, R. Soehardjo and R. Machjar Angga Koesoemadinata can be considered the pioneers of Indonesian art music. It was through the idea of musik seni that the Indonesian and Dutch musical exchange occurred at the deepest level and in a highly productive manner. Since these composers were living in a bi-musical world, their works were strongly characterized by an endeavour to synthesize indigenous and Western musical tradition, an idea that has dominated the most recent contemporary art music movement in the global context.

Let me now discuss how the Dutch composers who were living in East Indies in the early twentieth century also came up with similar musical ideas, i.e. combining the aesthetics and materials of Eastern and Western music in their works.

\section{Indies Composers and Musical Life in the Colony}

Driven by economic growth, by the turn of the twentieth century colonial society had developed a significant market for Western classical music. According to $\mathrm{H}$. van de Wall, a prominent music critic at that time, in the first couple of decades of the twentieth century an enthusiastic musical life had developed among the European communities living in all urban centres of the Archipelago. As a result, this intense musical life enriched the spiritual life and culture of colonial societies substantially (see Van de Wall 1923). Wright also writes:

The residents of Batavia have a keen appreciation of good music, and these musical treats, for so they may be called, are always largely attended by the members of the club and their friends (Wright 1909: 451).

Nieuwenhuys (1982) explained the significance of musical activity for colonial society in the East Indies as follows:

'A society without art, a society without culture', wrote Frenchman ChaillyBert in 190o. Indeed, one should not bother about things too enlightened in 
the old Indies, it does not mean that there were not many music activities; a clear advantage of being isolated. Playing music was in the first place a way to socialize, a part of social education. However, playing music for them can also become a serious activity (see Image 2$).{ }^{4}$

In the twentieth century, many foreign musicians came to the East Indies as immigrants. The influx of foreign musicians to the Archipelago can be divided into several phases (see Amir Pasaribu 1986: 8o-88; Van de Wall 1923: 275-276; Ido 1949, I and II). The first phase was the arrival of Italian street musicians. These musicians travelled around the streets of Batavia with their violins, flutes or harmoniums. Small local opera or circus companies also employed some of these musicians. The second phase was the arrival of Russian musicians who had fled the Bolshevik revolution. This group of musicians came in several waves. The first wave was the arrival of music instructors from the Russian conservatory in 1915. Among them, according to Amir Pasaribu, was the 'well-known' Moskwa Trio who resided, respectively, in Solo, Yogyakarta and Bandung and became music teachers. The second wave was the arrival of an opera troupe led by Feodorof in 1920. Then a group of musicians, including Shevchuk (clarinettist), Neudachin (clarinettist), Vondracek (cellist) and Varfolomeyef (cellist-conductor), came in $1925 .{ }^{5}$ The last group of Russian musicians to come to the East Indies was a Balalaika orchestra in 1930.

In 1929, an Italian opera troupe also arrived in the East Indies. Among the musicians who stayed in Batavia were Ms Boskin, Mulloni (clarinettist) and Pelegati (cellist). A year later, a number of musicians also came from Holland. However, according to Amir Pasaribu, the only name his informants recalled was Nek Heim, a violinist. In 1932-33, a large group of musicians came from Hungary to live in the East Indies. Among these musicians were Vidor von Jechim (violinist) and Setet (violinist), whose virtuosity became a legend among indigenous classical musicians. The next phase was an influx of musicians from the former Czechoslovakia in

4 Translated from the Dutch: 'Une société sans art, sans culture', schreef de Fransman Chailly-Bert in 1900. Inderdaad, met al te verheven dingen moest men in het oude Indie niet aankomen, maar er werd wel heel gemusiceerd. Een voordeel van de isolatie, Musiceren was in de eerste plaats een gezelschapsspel, behorende bij de sociale educatie, maar soms ook was de muziekbeoefening een serieus bedoelde bezigheid' (Nieuwenhuys 1982: 138).

5 These musicians mostly lived in Central Java and had a significant role in providing musical training to indigenous music students at the local music conservatory in Yogyakarta (SMIND) in the 1950s. 


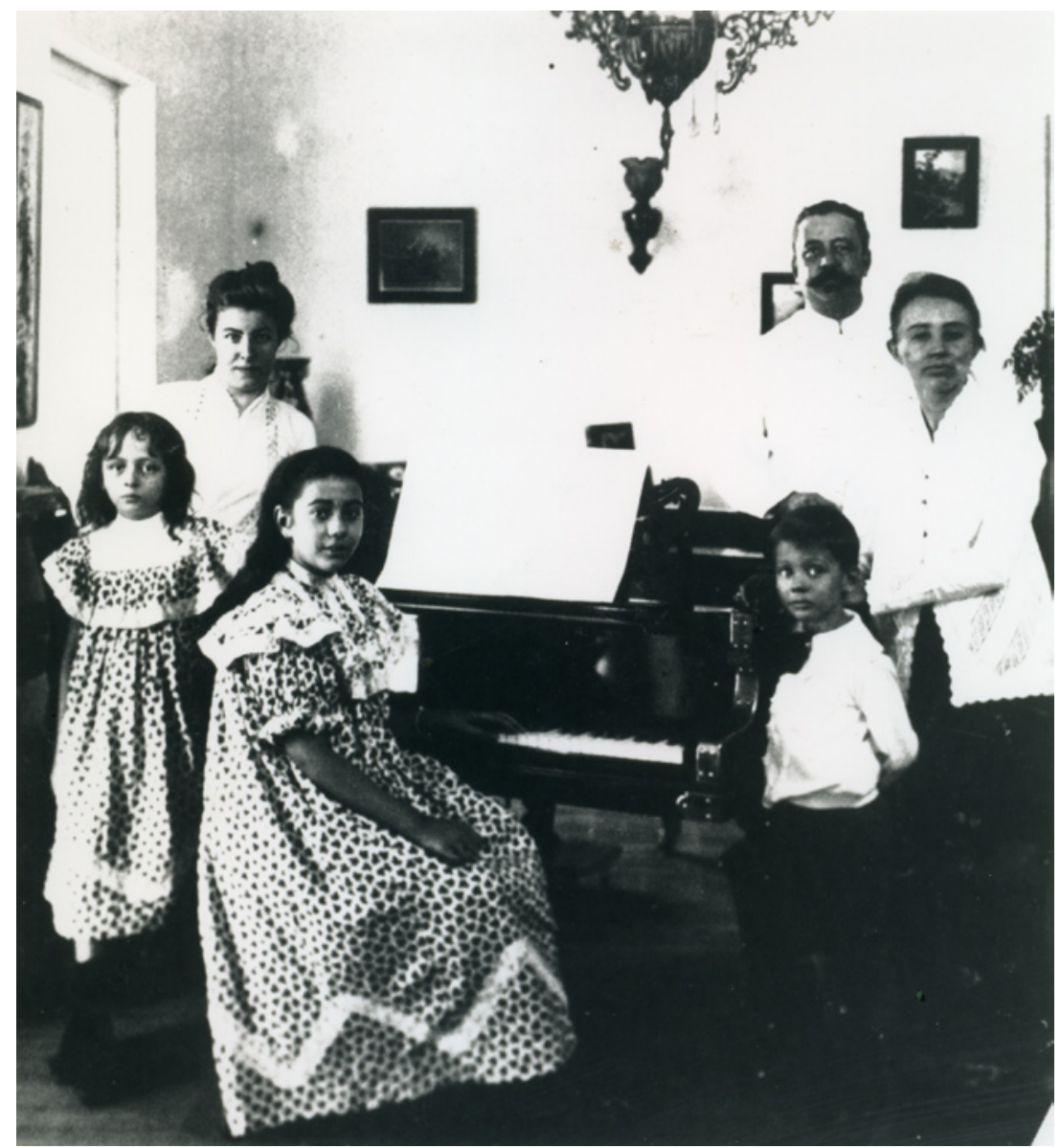

Image 6.2 Indies family with their music activity (KITLV 31931).

1937. Among them were Rosenberg (pianist) and Renner (violinist) who were also well-known among the indigenous musicians. In the same year, yet more musicians arrived from Holland: Arie Noteboom, who worked at the well-known Homan Hotel (Bandung) and Wiener Schramelorkest.

The largest numbers of musicians who came and lived in the East Indies, according to Amir Pasaribu, were musicians from Manila, Philippines. However, most of these were jazz musicians rather than classical. It was these musicians, who were responsible for the development of jazz and dance music in Indonesia, and who dominated the urban musical scene in the Archipelago until the 1940s. In 1948, the Dutch colonial 
government officially brought a large symphony orchestra consisting of 65 members to Batavia. This orchestra was called the Radio Philharmonic Orchestra and was led by Ivan Baarspul.

In addition to these large influxes, there were also musicians who came to the East Indies alone. Among them were Willy van Swers, Ms van de Wissel and Frans Wiemans, all of whom taught piano in Bandung, and James Zwart who taught composition in Jakarta. Amir Pasaribu himself was one of Zwart's students. Among these immigrant musicians were also instrument makers such as Belle (Amir Pasaribu 1986: 83). In addition to providing private music lessons, some of these immigrant musicians had positions such as conductors and music instructors at the courts of Surakarta, Yogyakarta, Langkat (East Sumatra) and Kutai (East Kalimantan). Others became staff musicians in clubs, hotels, and the military.

As a result of this long and steady influx of musicians from abroad, the musical scene in urban centres in the Archipelago was very active. These immigrant musicians were also able to enhance the quality of local musical performances. For instance, travellers considered a symphony orchestra in Batavia, associated with De Concordia and led by Nico J. Gerharz (1905-1916), to be the best symphony orchestra in Asia (see Van de Wall 1923: 275-276). Buitenweg also writes:

Up to 1904, there were not many works being performed except for dance music pieces, opera fantasies and airs. Gerharz had the courage to break this convention and performed music specifically written for symphony orchestra and featuring soloists. He was the man who first introduced works written for symphony orchestra in 1905. This was a fundamental change in the musical life in the capital. Finally, this raised the quality of the orchestra to a higher level that allowed them to compete with European orchestras (italics are mine). In the next few years they also performed works such as Berlioz's Carnaval Romain, Charpentier's Impressions d'Italie, Tchaikowsky's Symphony Pathetique, Dvorak's New World Symphony, and RimskyKorsakoff's The Scherezade. These concerts had a significant role in Concordia's activities and were very important to all music lovers of Batavia, including all the members of the social clubs in the city. ${ }^{6}$

6 Translated from the Dutch: 'Waren tot aan zijn optreden in 1904 niet veel anders dan dansmuziek, operafantasieën en parafrasen ten gehore gebracht, Gerharz durfde met deze sleur te breken en voor orkest geschreven werken te doen uitvoeren, waarbij ook solisten optraden. Hij was het, die de symphonie-concerten invoerde, die in 1905 begonnen, als het ware een omwenteling brachten in het muzikale leven van de hoofdstad en uiteindelijk de Stafmuziek op een hoogte brachten, dat zij me Europese orkesten van naam kon wedijveren. In de loop der jaren werden onder meer stukken ten gehore gebracht als Carnaval Romain van Hector Berlioz, Impressions d'Italie van Charpentier, Tsaikowski's 
News of the popularity of this symphony orchestra reached the Netherlands and became one of the most striking aspects of the colony for the Dutch who had just arrived. Moreover, in his book, Wright mentions that the outdoor concerts in Surabaya always attracted a large audience because of their high standard of performance (Wright 1909: 515).

One of the most significant developments in the colonial musical life in the twentieth century was the foundation of an organization called Kunstkring ('Art Circle') in many urban centres. One of the main activities of this organization was to bring foreign music groups to the colony to give concerts in many cities in the Archipelago. This was made possible due to the strategic location of the East Indies and the availability of Dutch sea transportation, which, since the 19th century, could bring people from Holland to the Dutch, French and British colonies in the Pacific and elsewhere. In the early twentieth century, each group of musicians that came from Europe to Australia, their main destination, had to go through the East Indies. Therefore, colonial society's art organizations in the Archipelago could invite them to come and perform in their cities.

The first Kunstkring was founded in Batavia on the 17th of September 1901 and was led by Carpentier Alting (Van de Wall 1923: 271). In 1914, all of the Kunstkring in the colony were connected under the name of de Bond van Kunstkringen ('Art Circle Association') (see Pino and De Boer-Pino 1998: 41).

In addition to Kunstkring, new theatre halls and clubs were established, such as Schouwburg and De Mangkunegaran Sociëteit in Surakarta. According to Buitenweg, in Central Java, Yogyakarta with its sociëteiten became a barometer of cultural activity. The Art Circle in this city was also active in inviting foreign musicians to come and give concerts.

Stirred by the new interest in Asian music in the late 19th century Europe, foreign musicians came to the colony not only to perform their music but to learn about indigenous music as well. Charles Wehle, a European pianist-composer who visited the colony in the 1860 , had already tried to incorporate indigenous music into his compositions (Notosudirdjo 1990:109). However, this idea was not popular before the turn of the twentieth century, when gamelan influence was recognized in the music of Claude Debussy. There were Dutch composers and (ethno) musicologists

Symphonien Pathétique, Aus der neuen Welt van Dvorak en de Scherezade van RimskyKorsakoff. Deze concerten hebben in belangrijke mate bijgedragen tot de roem van Concordia en alle Bataviaase muziekliefhebbers waren dan ook lid van de sociëteit' (Buitenweg 1966: 106). 
interested in kroncong and gamelan at this time. Among them were Dirk Schäfer, Emiel Hullebroeck, Bernard van den Sigtenhorst Meyer and Henk Bading (Grooss 1972: 122-132). This cultural contact encouraged van den Sigtenhorst Meyer to use Noto Soeroto's poem for his compositions. ${ }^{7}$

The development of the colonial musical scene at the turn of the twentieth century also produced prominent critics and composers who made significant contributions to the emergence of contemporary East Indies musical life. Among these critics and composers were Hans van de Wall (critic), Otto Knapp (critic), van Geuns (critic), Paul Seelig (composer), Fred Belloni (composer), Constant van de Wall (composer) and W.F. Siep (composer-conductor). Born into a bi-musical context, Seelig, Belloni, and Van de Wall developed their interests in kroncong and gamelan in their childhood (Grooss 1972: 128).

Seelig, for instance, grew up in Semarang and used to attend gamelan concerts in the houses of the Bupati's (regents) of Semarang, Jepara, and Demak. In 1890, Seelig went to Leipzig to study violin, piano, theory and conducting at the local conservatory founded by Mendelssohn. In 1894, he returned to Java and joined his father's orchestra. In addition, he also taught violin and piano. In 1897, he went back to Europe to study composition with Felix Weingartner. Here, Seelig had an opportunity to pursue his career surrounded by prominent European composers such as Hugo Wolff, Gustav Mahler, Richard Strauss, Max Reger, Claude Debussy, Manuel de Falla and Maurice Ravel. It was at this time that he corresponded with Ravel about gamelan (Grooss 1972: 128).

In 1900, Seelig came back to his homeland and became the music director for the Kasunanan court symphony orchestra. Here, Seelig learned how to play gamelan. Equipped with this knowledge and skill, he began to employ elements of gamelan in his compositions, among others Gendhing Djawi, Lagu-lagu Opus 34, Bimo Koordho, Marche Javanaise, Opus 14 and Trois Danses Javanaises.

Like Seelig, Constant van de Wall (born in Surabaya in 1861) also went to Europe to study music along with his brother, Hans van de Wall. In 1882, he went to The Hague to study with J.A. Ackerman, and subsequently with Friedrich Gernshein in Berlin. According to Grooss (1972: 122-132), in 1917 van der Wall returned to Surabaya and became an important music figure in town. While Seelig used gamelan elements as his compositional

7 Noto Soeroto was a Javanese nationalist poet who resided in the Netherlands in the early 20 th century. 
materials, C. van de Wall was more interested in using Malay songs for his compositions (see the contribution by Mak van Dijk to this volume).

Fred Belloni (born in Bukit Tinggi, West Sumatra in 1891), on the other hand, was interested in employing kroncong in his works. ${ }^{8}$ Trained as a violinist during his youth, Belloni played in the Wilhelmina Orchestra that belonged to his own school, the Batavia Kweekschool and Concordia Respavae Crescunt or CRC orchestra. He also often performed in a piano duo with an Ambonese pianist, Willy Adeboi. ${ }^{9}$ Belloni can be said to be the first composer of popular music in the colony. He was known as a composer of oud indische liedjes (songs of the old Indies), a genre of old Dutch popular song (see Amir Pasaribu 1986: 64-67). Many of his works were based on these Old Dutch songs. According to Amir Pasaribu, his most interesting orchestra work is entitled Legende de Borobudur.

In 1922, Belloni moved to Bandung and lived there until 1928. Seelig, who also resided in Bandung at that time, sometimes performed Belloni's compositions with his orchestra (Grooss 1972: 127). Most of his compositions, according to Amir Pasaribu, were recorded during this period. In the 1930s, Belloni had an opportunity to record his music with the Columbia Symphony Orchestra in London. Among his soloists were Sophie HaasePeineman (soprano) and Freddy van Kroon-van Drunen (tenor). Since kroncong was popular at that time, Belloni's works were more widely performed in the colony than those of his other two colleagues.

The practice of incorporating Indonesian indigenous music as an element of composition seemed to be characteristic of Indies composers' works in that era. If the three abovementioned composers were interested in utilizing the Javanese gamelan, Malay songs and kroncong music as their melodic materials, W.F. Siep, the Batavian composer, utilized Sundanese gamelan. His composition entitled Uit Preangerdreven (for piano and orchestra) treated melodies appropriated from Angklung (bamboo rattle music), Ronggeng dance music, and gamelan (Kebo Giro) as motifs of the composition. ${ }^{10}$ Siep's music, along with that of his colleagues, appeared to represent contemporary Indies music in concert repertoires in the era.

8 Due to its Portuguese origin, until the 196os kroncong was the only indigenous popular music genre to employ the Western diatonic scale and the concept of functional harmony, albeit in a very basic form (see fig. 15). The typical instruments employed in kroncong today are the ukulele, melodic guitar, pizzicato cello, violin and transverse flute.

9 He happened to be my first piano teacher.

10 Deli Courant, 24 September 1924. 
Since the initial stage of creative musical activity in the twentieth century East Indies, the local composers' bi-musical environment seemed to be able to produce a unique musical hybrid that combined the aesthetics of Eastern and Western music. Within the same period, both groups of the aforementioned Indies composers and indigenous composers such as Ki Hadjar Dewantara, Soerjo Poetro, Atmadarsana, R. Soehardjo and R. Machjar Angga Koesoemawinata arrived at the same musical idea, albeit through different ideological paths.

Based on this fact, I would argue that the encounter of indigenous Indonesian music and the 400 year history of Dutch musical practice in the Archipelago was able to produce a new music aesthetics that later contributed significantly to the evolution of musical modernism in the twentieth century. This new aesthetics drew, particularly, on the elements of gamelan and European classical music. In the global perspective, it has strongly influenced composers such as Colin McPhee, Benjamin Britten, Lou Harrison, John Cage, Karlheinz Stockhausen, Iannis Xenakis, Toru Takemitsu, Jose Maceda, Ton de Leeuw, Louis Andriesen, Paul Gutama Soegijo, Peter Sculthorpe, Jack Body, Steve Reich, Paul Dresher and entire new generations of North American, European, and Asia-Pacific composers who have developed experimental gamelan ensembles and compositions internationally over the past three decades.

\section{The New Musical Synthesis in the Global Context}

Among the most important musicians responsible for generating this new global musical development in the twentieth century were Dutch ethnomusicologist Jaap Kunst and Canadian composer Colin McPhee. Based on his extensive research, Jaap Kunst, a Dutch bureaucrat who defined his professional career as a music scholar by studying gamelan, produced a seminal book entitled De toonkunst van Java in 1934 (see Kunst 1934, 1973, and the chapter by Djajadiningrat and Brinkgreve in this volume). Impressed by his work, a young American composer turned ethnomusicologist, Mantle Hood went to Holland and studied with Jaap Kunst. In the 196os, along with Colin McPhee, Mantle Hood introduced lessons on gamelan music and composition at UCLA. During this period, Hood and his student, Robert Brown, brought Javanese as well as Balinese gamelan instructors to the United States. As a result, many young generations of American composers such as Terry Riley and Steve Reich spent time in the West Coast and studied gamelan. 
Several years later, Terry Riley came up with a composition entitled In $C$, which indicated the birth of a new aesthetic in music called minimalism or repetitive music. In due course, Steve Reich's works brought this new musical aesthetic and movement into maturity. $\operatorname{In} C$, and many of Reich's works, were strongly influenced by Balinese gamelan and McPhee's composition called Tabuh-Tabuhan, which also drew heavily on Balinese music. As it turned out, Riley's and Reich's works have inspired and influenced many other composers from across the globe, including Dutch composer, Louis Andriesen in his composition called De Staat and his works for Hoketus ensemble.

On the other hand, the late senior Dutch composer Ton de Leeuw received influences directly from his gamelan study with Jaap Kunst. In 1975, de Leeuw composed a piece for gamelan called Gending. Today, two of his former Indonesian students, Paul Gutama Soegijo and Sinta Wulur developed this new musical tradition extensively in Germany and Holland. In Germany, Soegijo founded an experimental gamelan group called Banjar Gruppe. Sinta Wulur also did the same thing in Holland. Her group is called Multifoon.

Through their compositions, the new musical tradition that was developed in the early twentieth century, both by indigenous Indonesian composers and Indies composers, have continued to flourish in fruitful ways on the European continent. Yet, in the archipelago itself, gamelan music has never ceased to be transformed into a new musical expression by the younger masters, such as I Nyoman Windha, AL Suwardi, I Wayan Sadra, and Rahayu Supanggah who, direct and indirectly, drew their musical inspirations from the West.

\section{Conclusion}

To conclude, I would argue that the encounter of the Indonesian and Dutch musical practices during the colonial time bears significant results for the development of musical modernism in the twentieth century. Driven by two different agendas, indigenous Indonesian composers and their Indies counterparts arrived at the creative endeavour that synthesized Eastern and Western musical aesthetics. The encounter, I would argue, has proven that both indigenous Indonesian and European musical traditions were capable of providing solid musical foundations, ingredients and inspiration to nurture contemporary music theory and practice for the future generations. The most recent worldwide musical movement involving 
gamelan and Western instruments, generated by composers such as Greg Schiemer and I Nyoman Windha, along with music ensembles such as Kronos Quartet, Bang On A Can, Multifoon, and the Indonesian National Orchestra provide strong evidence for the above contention.

\section{References}

\section{Bibliography}

Bambang Sokawati Dewantara, see Dewantara, Bambang Sokawati

Buitenweg, Hein. Soos en samenleving in tempo doeloe. Den Haag: Servire, 1966.

Christensen, Dieter. 'Erich M. von Hornbostel, Carl Stumpf, and the institutionalization of comparative musicology', in: Bruno Nettl and Philip W. Bohlman (eds), Comparative Musicology and Anthropology of Music, pp. 201-209. Chicago and London: University of Chicago Press, 1991.

Dewantara, Bambang Sokawati. Nyi Hadjar Dewantara dalam kisah dan data. Jakarta: Gunung Agung, 1979.

—. 100 tahun Ki Hadjar Dewantara. Jakarta: Pustaka Kartini, 1989a.

—. Ki Hadjar Dewantara ayahku. Jakarta: Pustaka Sinar Harapan, 198gb.

Dewantara, Ki Hadjar. Pola-wasita. Kitab soeloeh pendidikan. Kitab ke I. Jogjakarta: Madjelis Peroesahaan Kitab dari Persatoean Taman Siswa di Mataram-Jogja, 1933.

—. Dari kebangkitan nasional sampai Proklamasi Kemerdekaan. Djakarta: NV Pustaka Penerbit Endang, 1952.

—. Karja: Bagian IIA: Kebudajaan. Jogjakarta: Percetakan Taman-Siswa, 1967.

Grooss, Rosalie. De krontjong-guitaar. Den Haag: Uitgeverij Tong Tong, 1972.

Hadiwidjana. 'De Javaansche zang onder de regelen van de westersche muziek-techniek', Djåwå 5: 342-343, 1925 .

Hatta, Mohammad. Permulaan pergerakan nasional. Jakarta: Idayu Press, 1977.

Ido, Victor. Indië in den gouden ouden tijd. Bandoeng: N.V. v/h Nix. Two vols, 1949.

Ki Hadjar Dewantara see Dewantara, Ki Hadjar Koesoemadinata, Raden Machjar. 'Het muziekonderwijs voor inheemse kinderen', Gedenkboek H.I.K. Bandoeng 1866-1941, pp. 6o-77. Batavia: Volkslectuur, 1941.

Kunst, J. De toonkunst van Java. 's-Gravenhage: Nijhoff, 1934.

—. Music in Java. Its history, its theory, and its techniques. The Hague: Nijhoff, 1973.

Lindsay, Jennifer Mary. 'Paku Alaman: The foundation and functions of a Javanese minor court in the nineteenth century'. MA thesis, Ithaca, Cornell University, 1980.

—. Klasik, kitsch, kontemporer: sebuah studi tentang seni pertunjukan Jawa. Yogyakarta: Gadjah Mada University Press, 1991.

Nieuwenhuys, R. Komen en blijven: Tempo doeloe - een verzonken wereld: Fotografische documenten uit het oude Indië 1870-1920. Amsterdam: Querido, 1982.

Notosudirdjo, R.F.S. 'European music in colonial life in 19th century Java: A preliminary study'. Thesis (M.M.), University of Wisconsin-Madison, 1990.

Pasaribu, Amir. Analisis musik Indonesia. Jakarta: P.T. Pantja Simpati, 1986.

Pino, A.M. and De Boer-Pino, J. Komedie stamboel en andere verhalen uit de praktijk van het Binnenlands Bestuur op Java, 1913-1946. Leiden: Rijksuniversiteit Leiden, 1998.

Poetro, R.M.A. Soerjo. 'Beschouwing over Java's nationale toonkunst', in: Sosro Kartono, Noto Soeroto and Surya Ningrat (eds), Soembangsih: Gedenkboek Boedi-Oetomo, 1908-20 Mei-1918. Amsterdam: Tijdschrift Nederl. Indië Oud \& Nieuw. [Special issue.] 1918.

Poeze, Harry A. In het land van de overheerser: Indonesiërs in Nederland, 1600-1950. Dordrecht-Holland/Cinnaminson-USA: Foris, 1986. 
Shiraishi, Takashi. An age in motion: Popular radicalism in Java, 1912-1926. Ithaca and London: Cornell University Press, 1990.

Sumarsam. Gamelan: Cultural interaction and musical development in Central Java. Chicago and London: University of Chicago Press, 1995.

Surjomihardjo, Abdurrachman. Pembinaan bangsa dan masalah historiografi. Jakarta: Yayasan Idayu, 1979.

Susanto S.J., Budi, (ed.). Harta dan surga: Peziarahan Jesuit dalam gereja dan bangsa Indonesia modern. Yogyakarta: Peberbit Kanisius, 1990.

Toonkunst. 'Toonkunst in de toekomst', Wederopbouw (May): 73-77, 1920.

Wall, H. van de. 'Westersche muziek, tooneel en literatuur', in: L.F. van Gent, W.A. Penard, and D.A. Rinkes (eds), pp. 275-279. Gedenkboek voor Nederlandsch-Indië ter gelegenheid van het regeeringjubileum van H.M. de Koningin, 1898-1923. Batavia-Weltevreden/ Leiden: Kolff, 1923.

Wright, Arnold. Twentieth century impressions of Netherlands India: Its history, people, commerce, industries, and resources. London: Lloyd's Greater Britain Publishing Company, 1909 .

Newspapers and Journals

Deli Courant

Hindia Poetra

Mudato (1919)

Nederlandsch-Indië Oud en Nieuw (NION), 1916-1924

Oedaja, (1930)

Wederopbouw

Weekblad voor Indië, April 1920-April 1921 